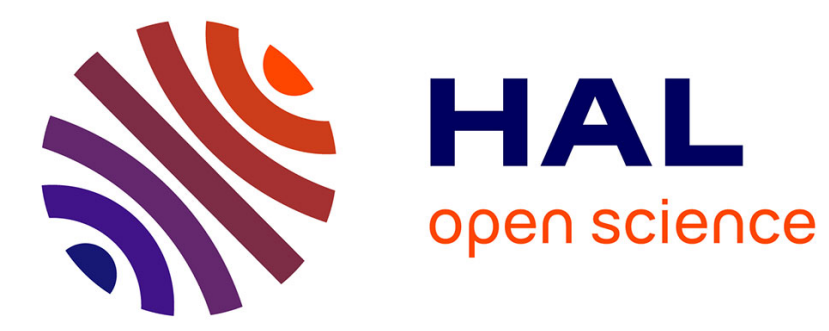

\title{
Does uncertainty matter for loan charge-offs?
}

Laetitia Lepetit, Frank Strobel, David G. Dickinson

\section{To cite this version:}

Laetitia Lepetit, Frank Strobel, David G. Dickinson. Does uncertainty matter for loan chargeoffs?. Journal of International Financial Markets, Institutions and Money, 2012, 22, pp.264 - 277. 10.1016/j.intfin.2011.09.006 . hal-01098926

\section{HAL Id: hal-01098926 https://hal.science/hal-01098926}

Submitted on 30 Dec 2014

HAL is a multi-disciplinary open access archive for the deposit and dissemination of scientific research documents, whether they are published or not. The documents may come from teaching and research institutions in France or abroad, or from public or private research centers.
L'archive ouverte pluridisciplinaire HAL, est destinée au dépôt et à la diffusion de documents scientifiques de niveau recherche, publiés ou non, émanant des établissements d'enseignement et de recherche français ou étrangers, des laboratoires publics ou privés. 


\title{
Does uncertainty matter for loan charge-offs?*
}

\author{
Laetitia Lepetit \\ Université de Limoges, LAPE, Limoges, France \\ Email: laetitia.lepetit@unilim.fr \\ Frank Strobel \\ University of Birmingham, Department of Economics, Birmingham, UK \\ Email: f.strobel@bham.ac.uk (corresponding author) \\ David G. Dickinson \\ University of Birmingham, Department of Economics, Birmingham, UK \\ Email: d.g.dickinson@bham.ac.uk
}

November 2011

${ }^{*}$ An early version of this paper was prepared for the Asia-Link human resource development project: Euro-Philippines Network on Banking and Finance, Safety and Soundness of the Financial System (Asialink/ASIE/B7-3010/2005/105-139), coordinated by the Université de Limoges. We are grateful to Keldon Bauer, Iftekhar Hasan, Céline Mesliers, Philippe Rous, Alain Sauviat, Amine Tarazi, Lawrence J. White, and an anonymous referee for their valuable comments. We also thank participants at the Financial Management Association Annual Meeting 2009, the Congrès Annuel de l'AFSE 2008, the Royal Economic Society Conference 2008, and the Midwest Finance Association Meeting 2008. All remaining errors are ours. 


\section{Introduction}

Recent events have refocused the interest of regulatory authorities and accounting standard setters on the effectiveness of the established regulatory and accounting framework for banks, particularly in a context of increasing international harmonization regarding these issues. In the context of loan loss accounting for banks, some of the discussion touches crucially on the long-standing debate regarding what level of discretion is the most appropriate. Accounting standard setters, as stressed by Benston and Wall (2005), appear to largely prefer rules to discretion in order to assure transparent, unbiased loan-loss reporting for general-purpose users of financial statements, such as investors. Bank supervisors, on the other hand, are predominantly concerned with assuring that banks are adequately capitalized and can efficiently fulfill their financial intermediation role, without opposing bank managers' accounting discretion per se. ${ }^{1}$ This is in line with the established view of Watts and Zimmerman $(1986,1990)$ that such discretion could either be wealth enhancing for all contracting parties, or alternatively make the manager exercising the discretion better off at the cost of some of the other contracting parties. ${ }^{2}$

While there is an extensive literature on discretionary behavior in loan loss provisioning, ${ }^{3}$ this paper focuses on the loan charge-off behavior of banks which can have similarly important discretionary elements, but has been previously studied to a lesser extent. One strand of the existing theoretical and empirical literature has focused on the Japanese banking crisis in the 1990s. Cargill et al. (1997) argue that Japan's government adopted regulatory forbearance, e.g. relaxation of bank capital requirements, in order to "buy time" during the collapse of its real estate and stock market bubbles. Japanese banks delayed charging off non-

\footnotetext{
${ }^{1}$ This motivates, e.g., the current discussions between the Basel Committee on Banking Supervision and the International Accounting Standards Board regarding the possible implementation of forward-looking loan loss provisioning systems to reduce the procyclicality of bank lending, which would however require a reform of the Fair Value Accounting system based on IAS 39 (Basel Committee on Bank Supervision, 2009).

${ }^{2}$ More generally, the first type of discretion is thus welfare enhancing in a Pareto sense, while the second is not.

${ }^{3}$ See e.g. Anandarajan et al. (2007) for a survey.
} 
performing loans, and even engaged in "forbearance lending" where banks extend further loans to troubled borrowers in the hope that economic conditions might recover (Baba, 2001; Sekine et al., 2003; Chen and Chu, 2003; Peek and Rosengren, 2005; and Schüle, 2007).

However, discretionary behavior in banks' loan charge-off decisions is not necessarily confined to crisis episodes like the Japanese one. A related empirical literature highlights that US banks might have used discretionary loan charge-offs for capital management purposes prior to the 1989 regulatory change in bank capital ratio determination (Moyer, 1990; Beatty et al., 1995; Collins et al., 1995; and Kim and Kross, 1998). Net charge-offs are deducted from loan loss reserves, ${ }^{4}$ which formed then part of primary capital; thus banks were able to decrease net charge-offs in order to increase their regulatory capital. For banks this represented a less costly way to increase regulatory capital than raising equity or decreasing risk exposure; for a regulator, on the other hand, this amounts to a "fictitious" increase in regulatory capital, and would therefore be undesirable. These incentives have since been severely reduced, as loan loss reserves from Basel I onwards enter at most into Tier 2 capital (Laurin and Majnoni, 2003). ${ }^{5}$

Alternatively, Liu and Ryan (2006) highlight a potential income smoothing objective related to discretionary loan charge-offs. Banks may have incentives to smooth their income in order to reduce investors' and regulators' perception of their risk, or due to bank managers' concerns about their job security (Fudenberg and Tirole, 1995). Banks could achieve such income smoothing by understating (overstating) their loan loss provisions when earnings are expected to be low (high) relative to their average earnings over the cycle. They could then attempt to obscure this behavior by trying to minimize fluctuations in loan loss reserves, in order to avoid regulatory and market scrutiny. This could be achieved through

\footnotetext{
${ }^{4}$ Note the accounting identiy: (loan loss reserves $)=($ loan loss provisions $)+($ lagged loan loss reserves) - (loan charge-offs).

${ }^{5}$ The Basel I accord allowed general loan loss reserves to count toward Tier 2 capital up to a maximum of $1.25 \%$ of risk-weighted assets. For banks using the IRB approach, Basel II changed this limit to $0.6 \%$ of credit-risk-weighted assets.
} 
exercising discretion over loan charge-offs, e.g. by accelerating charge-offs to offset higher loan loss provisions to keep loan loss reserves unchanged. As discretionary loan charge-off behavior motivated in this way essentially aims to deceive both regulators and investors, it would be deemed undesirable by both regulatory authorities and accounting standard setters.

In this paper, we add another aspect to this literature by stressing that discretion over the timing of charging off a non-performing loan could be economically justified in the following scenario: (i) there remains a positive probability the loan will be ultimately repaid, which might plausibly depend on general economic conditions, and (ii) the value of the potentially reclaimed collateral and the deadweight costs associated with loan foreclosure are similarly uncertain. To examine how variability in the market for collateral and general economic conditions can influence banks' discretionary behavior in loan charge-offs, we develop a stylized real options model of a bank's (optimal) decision whether or not to foreclose on and charge off a currently non-performing secured loan when there is the chance of full loan recovery and the expected present value of the potentially reclaimed collateral, minus the deadweight costs of loan foreclosure, are uncertain. ${ }^{6}$

We demonstrate, in line with real options theory, that the bank proves less willing to pursue the process of loan foreclosure and charge-off than in the classical certainty case. We further show that increased uncertainty about the bank's expected discounted loss from foreclosing on and charging off the loan, e.g. stemming from variability in the market for collateral, increases the bank's tendency to delay this process. An increased probability of loan recovery, as possibly driven by better general economic conditions, can either reduce or, more intuitively, increase the bank's willingness to delay the loan foreclosure and charge-off process, depending on the degree to which economic conditions affect the trend in the mar-

\footnotetext{
${ }^{6} \mathrm{Baba}$ (2001), in the context of the Japanese banking crisis, also uses a real options approach to examine the effects of uncertainty on banks' loan charge-off decisions; however, he focusses on the possible implementation of a government subsidy scheme and uncertain reputational repercussions from writing off non-performing loans as key driving factors instead. For standard treatments of real options methodology, see e.g. McDonald and Siegel (1986) and Dixit and Pindyck (1994).
} 
ket value of collateral.

Allowing a bank to exercise discretion in the timing of charging off a nonperforming loan is, in this context, equivalent to letting it properly take into account the real options value implicit in the loan charge-off decision. A welfare maximizing regulator might thus want to let banks pursue this kind of discretionary loan charge-off behavior, with the obvious problem of distinguishing it from the one stemming from the capital management and income smoothing objectives, while a more rules-focused accounting standards setter would presumably not.

We test empirically the hypothesis that banks, if otherwise unconstrained, might have discretionary behavior regarding loan charge-offs that is related to variability in the market for collateral and general economic conditions, consistent with the real options perspective taken above. In the United States, bank regulatory guidance dictates when most loans have to be charged-off, e.g. no later than 180 days for residential mortgages (the most common collateralized loan type), leaving little room for such discretionary behavior. In Europe, on the other hand, absence of strict rules regarding the timing of loan charge-offs is pervasive. We therefore test our implied hypothesis of "uncertainty dependence" in discretionary loan charge-offs using a panel of European banks over the period 1994 to 2005, controlling for the two alternative types of discretionary loan charge-off behavior motivated by capital management and income smoothing objectives.

Our results confirm the existence of a discretionary, uncertainty-related factor in European banks' loan charge-off behavior, which is consistent with the main features highlighted in our theoretical model. Our results further suggest the possibility that European banks might be smoothing their income while attempting to obscure this behavior through matching discretionary loan charge-offs. Capital management, on the other hand, does not seem to play a significant role in the loan charge-off behavior of European banks.

Section 2 now develops the model and discusses its results; section 3 describes and discusses our empirical analysis; and section 4 concludes the paper. 


\section{A stylized model of loan charge-offs under uncer- tainty}

We consider a stylized model of a bank holding a secured loan which in its current non-performing state has an expected present value of $N \leq 1$; the expected present value of the loan in its performing state is normalized to one. The bank faces the binary decision problem to either foreclose on and charge off this nonperforming loan now, or to wait and see if the loan recovers. We assume that the bank is otherwise unconstrained, i.e. we abstract from accounting and/or regulatory requirements; we also assume that the bank's only objective is to maximize the expected payoffs from that loan, i.e. it does not engage in income smoothing or capital management. These simplifications allow us to focus on the impact of uncertainty on the bank's loan foreclosure and charge-off decision, which would be more difficult to isolate in a more complex, if possibly more realistic, framework.

If the bank does go ahead with the process of loan foreclosure and chargeoff, the expected present value of the potentially reclaimed collateral, minus the deadweight costs associated with loan foreclosure, are assumed to be given by $R C \leq 1$. We can then define the bank's expected discounted loss if it does not immediately foreclose on and charge off the loan as $L_{n}=1-N$ (reflected in the amount of loan loss reserves set aside through loan loss provisions), and the corresponding expected discounted loss if it does proceed with the loan foreclosure and charge-off process as $L_{w}=1-R C$ (reflecting the resulting net charge-off).

To represent the non-performing loan's chance of recovery, the bank's expected discounted loss while postponing the process of loan foreclosure and chargeoff is assumed to follow the jump process $d L_{n}=-L_{n} d q$, where $d q$ is the increment of a Poisson process such that $d q=1$ with positive probability $\lambda d t$. This downward Poisson jump thus represents the chance of a full loan recovery, with mean arrival time $\lambda^{-1}$; this would generally depend on economic conditions. ${ }^{7}$

\footnotetext{
${ }^{7}$ One could e.g. imagine a borrower's financial situation being turned around by the arrival of
} 
On the other hand, as the value of the potentially reclaimed collateral and the deadweight costs associated with loan foreclosure are also uncertain, the bank's expected discounted loss from foreclosing on and charging off the loan is assumed to follow the geometric Brownian motion $d L_{w}=\phi L_{w} d t+\sigma L_{w} d z .^{8}$ In this specification, the trend rate $\phi$ is modelled as $\phi=\alpha-\eta \lambda$, where $\alpha$ is a collateral-specific trend rate, adjusted for "economic conditions" as proxied by a linear function of the Poisson parameter $\lambda$, with $\eta \geq 0$. Furthermore, $\sigma^{2}$ is the variance rate, and $d z \sim \mathrm{NID}(0, d t)$ is the increment of a Wiener process with $E(d z d q)=0$, implying that changes in future values of expected discounted losses from pursuing the process of loan foreclosure and charge-off are lognormally distributed, with the variance of their levels increasing in the time horizon.

The bank's choice problem then involves the comparison of the respective expected discounted losses from either delaying or going ahead with the process of foreclosing on and charging off the non-performing loan, taking the option value of waiting into account. Formally, the bank's decision implies solving the Bellman equation for the optimal stopping problem

$$
F\left(L_{n}, L_{w}\right)=\max \left\{L_{n}-L_{w}, \frac{1}{\mu d t} E\left[d F\left(L_{n}, L_{w}\right)\right]\right\}
$$

where $\mu>0$ is the appropriate risk-adjusted or discount rate, and $F\left(L_{n}, L_{w}\right)$ is the value of the option to foreclose on and charge off the non-performing loan, with $L_{n}-L_{w}$ the expected discounted benefit from pursuing the loan foreclosure and charge-off process. ${ }^{9}$ We can then derive the trigger value for the bank's option exercise as

new orders or contracts, a mechanism that could be reasonably represented by a Poisson process in this way.

${ }^{8}$ The expected discounted loss from pursuing the loan foreclosure and charge-off process, $L_{w}$, is heavily dependent on the value of potentially reclaimed collateral, which, as an asset price, could arguably be reasonably represented by a geometric Brownian motion. The combination of Poisson and geometric Brownian motion processes has furthermore the technical advantage of allowing a closed-form solution to the bank's optimization problem.

${ }^{9}$ Note that $L_{w}$ and $L_{n}$ represent expected discounted losses. 
Proposition 1 The bank will want to exercise the option to foreclose on and charge off the non-performing loan if

$$
\begin{aligned}
\frac{L_{n}}{L_{w}} \geq\left(\frac{L_{n}}{L_{w}}\right)^{*} & = \\
& \frac{\sigma^{2}-2 \phi+4(\mu+\lambda)+\sqrt{8(\mu+\lambda) \sigma^{2}+\left(2 \phi-\sigma^{2}\right)^{2}}}{4(\mu+\lambda)}>1
\end{aligned}
$$

for $\mu+\lambda-\phi>0$, where $\phi=\alpha-\eta \lambda$ and $\sigma^{2}$ are the (adjusted) trend and variance rate of the bank's expected discounted loss from foreclosing on and charging off the loan, $\mu$ is the discount rate, and $\lambda$ the probability of loan recovery.

Proof. See Appendix.

If the current ratio of expected discounted losses $\frac{L_{n}}{L_{w}}$ exceeds (or is equal to) the critical or trigger value $\left(\frac{L_{n}}{L_{w}}\right)^{*}$ derived in Proposition 1, the bank will want to exercise the option to foreclose on and charge off the non-performing loan instantaneously. If $\frac{L_{n}}{L_{w}}<\left(\frac{L_{n}}{L_{w}}\right)^{*}$, however, it will prefer to leave this option unexercised for the time being, i.e. display discretionary behavior by holding off on the foreclosure and charge-off process. As this trigger value is strictly (and potentially substantially) greater than one, the bank proves less willing to foreclose on and charge off the non-performing loan than in the classical certainty case. $^{10}$ This inertia is a natural consequence of the real options nature of the decision problem involved, and stems from the interaction of uncertainty about the payoffs from and irreversibility in the bank's loan foreclosure and charge-off decision.

We further examine how the inertia arising from the real options nature of the loan charge-off decision depends on the different underlying structural parameters of our model, resulting in

Proposition 2 The comparative statics effects of changes in $\sigma, \alpha, \eta, \mu, \lambda$ and $\phi$

\footnotetext{
${ }^{10}$ Note that $\left(\frac{L_{n}}{L_{w}}\right)^{*}=1$ in this case.
} 
(where $\phi=\alpha-\eta \lambda$ ), on the trigger value of relative expected discounted losses $\left(\frac{L_{n}}{L_{w}}\right)^{*}$ are

$$
\begin{gathered}
\frac{\partial\left(\frac{L_{n}}{L_{w}}\right)^{*}}{\partial \sigma}>0, \quad \frac{\partial\left(\frac{L_{n}}{L_{w}}\right)^{*}}{\partial \phi}=\frac{\partial\left(\frac{L_{n}}{L_{w}}\right)^{*}}{\partial \alpha}<0, \quad \frac{\partial\left(\frac{L_{n}}{L_{w}}\right)^{*}}{\partial \eta}>0, \\
\frac{\partial\left(\frac{L_{n}}{L_{w}}\right)^{*}}{\partial \mu}<0, \quad \frac{\partial\left(\frac{L_{n}}{L_{w}}\right)^{*}}{\partial \lambda}\left\{\begin{array}{lll}
\geq 0 & \text { for } & \eta \geq \eta^{*} \\
<0 & \text { for } & 0 \leq \eta<\eta^{*} \\
\text { where } & \eta^{*}=\frac{\sigma^{2}-2 \alpha+\sqrt{8 \mu \sigma^{2}+\left(\sigma^{2}-2 \alpha\right)^{2}}}{4 \mu}>0
\end{array}\right.
\end{gathered}
$$

Proof. See Appendix.

Increased uncertainty $(\sigma)$ about the bank's expected discounted loss from foreclosing on and charging off the non-performing loan increases the value of the option to wait. This raises the trigger value associated with the foreclosure and charge-off decision and thus increases the bank's tendency to delay it. Such uncertainty would stem largely from variability in the market for collateral, which for many loans will depend heavily on real estate prices. An increased (adjusted) trend $(\phi)$ in the bank's expected discounted loss from pursuing the loan foreclosure and charge-off process has the opposite effect on its willingness to go ahead with it; this could reflect long-term (downwards) developments in the market for collateral $(\alpha)$, worsened general economic conditions (as proxied by $\eta \lambda$ ), or a combination of these two. The stronger the degree $(\eta)$ to which economic conditions affect that trend, the stronger the bank's tendency to delay the loan foreclosure and charge-off decision.

Increasing the risk-adjusted or discount rate $(\mu)$ reduces the potential future benefits from postponing the process of loan foreclosure and charge-off, and thus leads to lower values of both the option to wait and the associated trigger value. An increased probability of loan recovery $(\lambda)$ could either lead to lower or higher values of the option to wait and the associated trigger value, depending on the level of the parameter $\eta$. For low enough levels of $\eta$, i.e. $\eta<\eta^{*},{ }^{11}$ a higher

\footnotetext{
${ }^{11}$ One can further show that $\frac{\partial \eta^{*}}{\partial \alpha}<0, \frac{\partial \eta^{*}}{\partial \sigma}>0$ and $\frac{\partial \eta^{*}}{\partial \mu}<0$.
} 


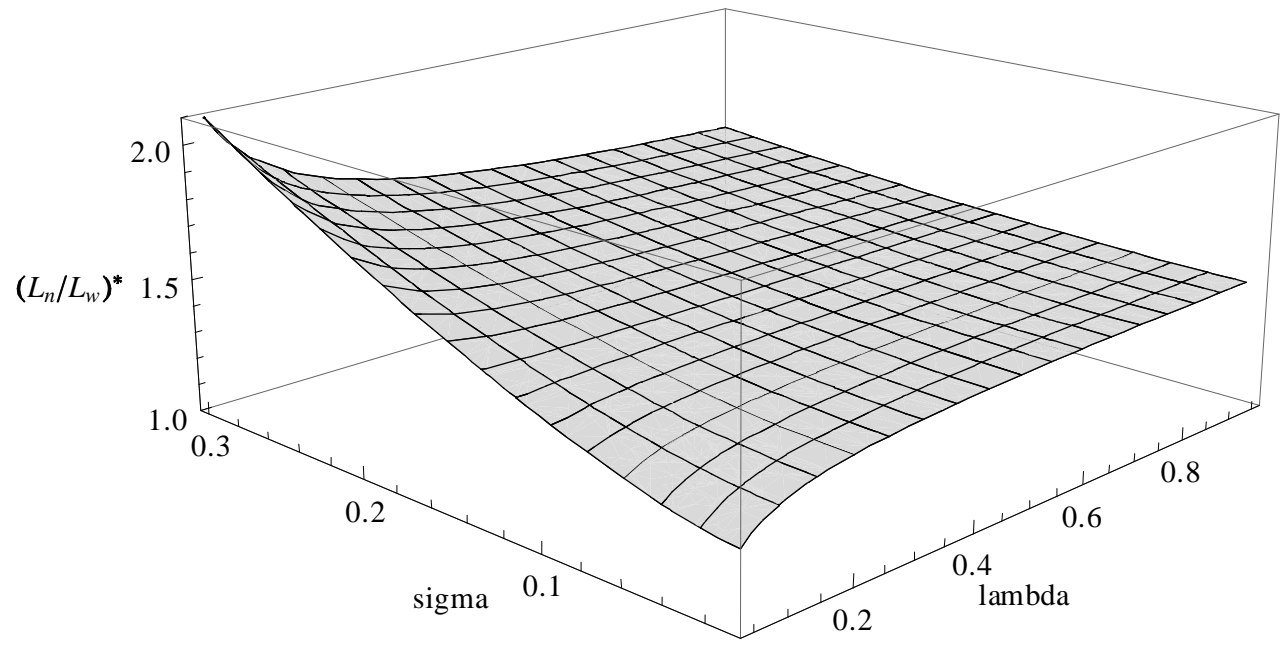

Figure 1: Trigger value as function of $\sigma$ and $\lambda$ (for $\alpha=0, \mu=0.05$ and $\eta=0.5$ )

probability of loan recovery, as plausibly driven by better economic conditions, could lower the potential future gains from delaying the process of loan foreclosure to the point of leading to overall lower values of the option to wait and the associated trigger value. This counterintuitive implication disappears, however, for large enough levels of $\eta$, i.e. $\eta>\eta^{*}$, generating the more intuitive result that banks' discretionary tendency to delay the loan foreclosure and charge-off process is strengthened by better general economic conditions increasing the chance for loan recovery, in addition to being also magnified by more variability in the market for collateral.

These results are illustrated in Figures 1 and 2 where we simulated the trigger values $\left(\frac{L_{n}}{L_{w}}\right)^{*}$ as functions of $\sigma, \alpha, \mu$ and $\lambda$. We note the potentially very significant magnitudes of those trigger values; this demonstrates the importance of variability in the market for collateral and general economic conditions affecting the chance for loan recovery for banks' discretionary behavior in loan charge-offs.

The main policy implication of our model is therefore that when a bank has the leeway to exercise discretion in the timing of its loan charge-offs, it can properly take into account the real options value implicit in the loan charge-off decision, which can be of a substantial magnitude; a welfare maximizing regulator might 


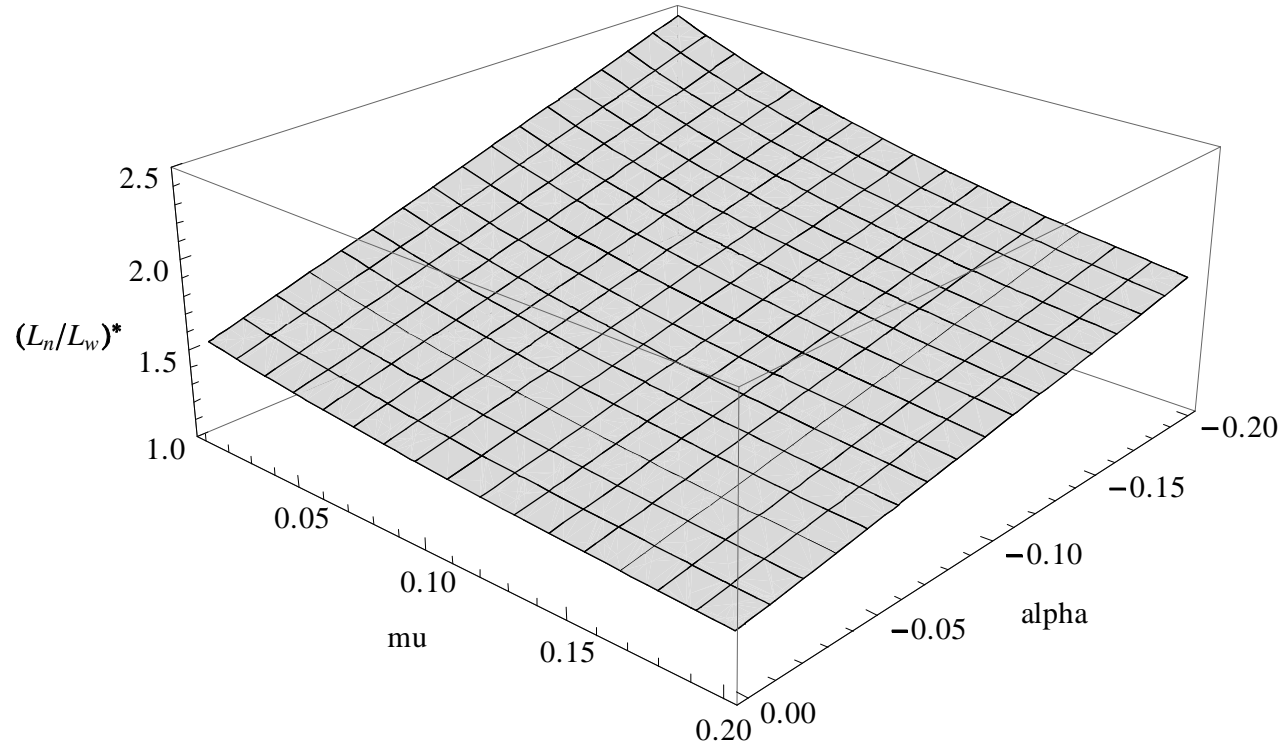

Figure 2: Trigger value as function of $\mu$ and $\alpha$ (for $\sigma=0.1, \lambda=0.2$ and $\eta=0.5$ ) generally approve of banks pursuing this kind of discretionary, optimizing behavior.

\section{Empirical analysis}

\subsection{Methodology and data description}

In Section 2 we demonstrated that banks' discretionary behavior in charging off non-performing loans might generally be related to variability in the market for collateral and general economic conditions. We test this hypothesis of "uncertainty dependence" in loan charge-offs, while controlling for possible capital management and income smoothing behavior as discussed in the introduction, using a panel of European commercial, savings and cooperative \& mutual banks over the period 1994 to 2005. Annual information on our core variables of interest (in particular net charge-offs, loan loss reserves and total capital ratio), which we extracted from BvD BankScope, is available only for 224 banks out of a Euro- 
pean total of 4853 (with 1 in Austria, 4 in Germany, 138 in Italy, 19 in Norway, 13 in Portugal, 39 in Spain and 10 in the UK). Table 1 gives some descriptive statistics for both our dataset and the full European sample of banks available in BankScope.

\section{[Insert Table 1]}

We represent general economic conditions by the output gap $\left(G A P_{j t}\right)$, calculated on quarterly GDP data using a standard Hodrick-Prescott filter to compute the output trend. We further proxy the discount rate with the three-month interbank rate $\left(R 3 M_{j t}\right)$; both the GDP and the interest rate series are provided by Datastream International.

Variability in the market for collateral should be related to that in the real estate market, so we use returns on real estate stock indices as a proxy; this choice is motivated by the fact that we extract conditional volatilities with a GARCH procedure, ${ }^{12}$ which requires higher frequency data. The $\operatorname{GARCH}(1,1)$ estimated using weekly data for each country $j$ has the specification

$$
\begin{gathered}
R E S_{t}=\delta+\beta R M_{t}+\varepsilon_{t} \\
h_{t}=\varpi+\gamma \varepsilon_{t-1}^{2}+\eta h_{t-1}
\end{gathered}
$$

where $R E S_{t}$ is the return of the national real estate stock index, and $R M_{t}$ the return of the national market index provided by Datastream International.

Equation (2) specifies a single-factor market model to characterize the conditional mean of the return of the national real estate stock index as the fitted values $R \hat{E} S_{t}$. Equation (3) is the $\operatorname{GARCH}(1,1)$ representation of the conditional variance, characterizing the current fitted variance $h_{t}$. We assume conditionally normal errors and use a quasi-maximum likelihood method with robust standard

\footnotetext{
${ }^{12}$ The GARCH (Generalised Autoregressive Conditionally Heteroscedastic) model, developed by Bollerslev (1986), is a widely used, parsimonious way to model (financial) time-series with time-varying volatility where volatility occurs in clusters (i.e. is "autocorrelated").
} 
errors ${ }^{13}$ to estimate the model. ${ }^{14}$ The weekly conditional means and conditional standard deviations are averaged and annualized as series $M_{j t}$ and $\sqrt{H_{j t}}$, respectively; these are interpreted as corresponding to the adjusted trend $(\phi)$ and uncertainty $(\sigma)$ characterizing the bank's expected discounted loss from pursuing the loan foreclosure and charge-off process.

We then estimate the following equation to determine the impact of variability in the market for collateral and general economic conditions on banks' net chargeoffs

$$
\begin{aligned}
N C O_{i t}= & \alpha_{1} N C O_{i t-1}+\alpha_{2} N P L_{i t-1}+\alpha_{3} T C R_{i t-1}+\alpha_{4} M_{j t}+\alpha_{5} \sqrt{H_{j t}} \\
& +\alpha_{6} G A P_{j t}++\alpha_{7} R 3 M_{j t}+\alpha_{8} G A P_{j t} \cdot \text { ISmooth }_{i t}+\xi_{i}+\mu_{i t}
\end{aligned}
$$

where $N C O_{i t}$ is the ratio of net charge-offs to gross loans of bank $i$; we introduce a lagged dependent variable to allow for the fact that charging-off a portfolio of non-performing loans may have an intertemporal dimension.

We also include several bank specific control variables, as in the related work of Moyer (1990), Beatty et al. (1995), Collins et al. (1995), Kim and Kross (1998), and Liu and Ryan (2006). Loan losses are controlled for by the lagged ratio of non-performing loans to gross loans $\left(N P L_{i t-1}\right)$; this variable should have a positive impact on net charge-offs. We also include the lagged total capital ratio $\left(T C R_{i t-1}\right)$ to allow for possible capital management. Banks might be able to increase their regulatory capital by decreasing their net charge-offs, which increases their loan loss reserves; the sign of the coefficient associated with the variable $T C R_{i t-1}$ is then positive if banks exercise discretion over current loan charge-offs to increase their regulatory capital when it is at a relatively low level in the previous period. ${ }^{15}$

\footnotetext{
${ }^{13}$ See Bollerslev and Wooldridge (1992).

${ }^{14} \mathrm{We}$ also ascertain the appropriateness of the $\operatorname{GARCH}(1,1)$ specification by testing each country model for joint significance of the GARCH parameters, and the absence of further autoregressive conditional heteroskedasticity in the residuals, using an ARCH LM test (Engle, 1982).

${ }^{15}$ With Basel I in force during our sample period, this effect should be limited; see footnote 5.
} 
Furthermore, Liu and Ryan (2006) observe that banks that try to smooth their income could attempt to obscure this behavior by trying to minimize fluctuations in loan loss reserves, in order to avoid regulatory and market scrutiny. This could be achieved through exercising discretion over loan charge-offs, e.g. by accelerating charge-offs to offset higher loan loss provisions to keep loan loss reserves unchanged. We control for this effect by including an interaction term between the output gap $\left(G A P_{j t}\right)$ and an index of the variability of banks' loan loss reserves $\left(I S m o o t h{ }_{i t}\right)$, which we construct as the difference from the sample mean of the inverse standard deviation of banks' loan loss reserve to gross loans ratio, as calculated using three-period moving windows. Banks obscuring their income smoothing over the cycle through discretionary charge-offs will display lower variability of loan loss reserves; in this scenario, our interaction term would have an expected positive sign, as it captures the discretionary net charge-offs of banks that both smooth their income and try to obscure this behavior as a function of the current economic condition.

For the variables suggested by the real options framework in Section 2, reflecting the variability in the market for collateral and general economic conditions, we then expect negative signs on the coefficients for the conditional means $\left(M_{j t}\right)$ and conditional standard deviations $\left(\sqrt{H_{j}}\right)$, a positive sign for the three-month interbank rate $\left(R 3 M_{j t}\right)$, whereas we are agnostic regarding the sign for the output gap $\left(G A P_{j t}\right) .{ }^{16}$

\subsection{Estimation results and discussion}

Our Equation (4) contains a lagged dependent variable and two variables estimated using a GARCH procedure, thus containing measurement error. We therefore estimate it by Generalized Method of Moments (GMM), using two-step versions of the estimators relying on first-differences (Arellano and Bond, 1991) and

\footnotetext{
${ }^{16}$ Note that higher trigger values imply lower contemporaneous loan charge-offs, leading us to expect the opposite of the signs given for $\sigma, \lambda$ and $\mu$ in Proposition 2. The implied sign for the (adjusted) trend in the (net) value of collateral is the same as that for $\alpha$ and $\phi$ in Proposition 2, however, as these are defined in terms of expected discounted losses from the loan charge-off.
} 
orthogonal deviations (Arellano and Bover, 1995) to remove cross-section fixed effects; our estimations are robust to cross-sectional variation in the time series correlation structure. ${ }^{17}$ We verified that the correlations between our explanatory variables are weak, performed Sargan tests of overidentifying restrictions to check on the validity of our instruments, and checked for absence of second-order serial correlation in the first-differenced residuals, which is required for consistency of the first-differences estimator used.

Table 2 presents the results for the estimation of Equation (4) using our two alternative estimators. The variable controlling for loan losses, $N P L_{i t-1}$, has a significant positive impact on net charge-offs, as expected. The coefficient on the lagged dependent variable $\mathrm{NCO}_{i t-1}$ is similarly positive and significant, demonstrating the intertemporal dimension of banks' charge-off behavior. The coefficient on the lagged total capital ratio $T C R_{i t-1}$ is not significant; this suggests that the hypothesis that banks manage their regulatory capital using loan charge-offs is not valid for our sample of European banks, reflecting their significantly reduced leeway to do so under Basel I regulations. The coefficient on the interaction term $G A P_{j t} \cdot I$ Smooth $_{i t}$ is only significant using orthogonal deviations; as it is positive in this case, our results are (weakly) supportive of the mechanism described by Liu and Ryan (2006), whereby banks that try to smooth their income attempt to obscure this behavior by exercising discretion over loan charge-offs.

Our empirical results confirm further the "uncertainty dependence" hypothesis that banks display discretionary behavior in loan charge-offs which is related to variability in the market for collateral and general economic conditions. The coefficients for the conditional means $M_{j t}$ and conditional standard deviations $\sqrt{H_{j t}}$ are both significant and negative; both higher growth and uncertainty in the real estate market thus lead to lower levels of contemporaneous net charge-offs. We find a significant negative relationship of the output gap $G A P_{j t}$ on net charge-offs; this is consistent with the case where $\eta \geq \eta^{*}$ in our model, confirming the (in-

\footnotetext{
${ }^{17}$ Note that the lagged variables and GMM used almost halve the numbers of observations that would be usable under simple OLS.
} 
tuitive) prediction that banks show greater inertia in charging off non-performing loans when economic conditions are relatively good. Finally, the coefficient on the three-month interbank rate $R 3 M_{j t}$ is significant and positive, further illustrating the intertemporal dimension in banks' loan charge-off behavior.

These results thus confirm the existence of a discretionary, uncertainty-related element in the way European banks charge-off non-performing loans, which is consistent with the main features highlighted in our theoretical model; welfare maximizing regulators should generally approve of banks pursuing their loan charge-off process in such a fashion. Capital management does not appear to play a significant role in European banks' net charge-off behavior. However, our results are indicative of the possibility that European banks could be smoothing their income while attempting to obscure this behavior through matching discretionary loan charge-offs. From a regulator's point of view, it might thus in practice be difficult to distinguish the (desirable) uncertainty-related element in European banks' loan charge-off behavior from the much less desirable income smoothing one. A more rules-focused accounting standards setter, on the other hand, would presumably equally disapprove of both types of discretionary behavior.

[Insert Table 2]

\subsection{Robustness and further issues}

We examine the robustness of our estimations along two dimensions. ${ }^{18}$ As the capital management hypothesis could be more relevant for poorly capitalized banks, we replace the total capital ratio $T C R$ with a normalized total capital ratio measure, defined as $\frac{T C R-8}{8}$ for the first quartile of $T C R$ and 0 otherwise, to test if this hypothesis holds only for those poorly capitalized banks; our results are unchanged, with the coefficient still being insignificant.

Given that Italian banks are heavily represented in our sample, we check whether our results might be an purely Italian phenomenon by running our Equa-

\footnotetext{
${ }^{18}$ Details are available from the authors on request.
} 
tion (4) on a sample excluding those Italian banks. The results for the three key variables reflecting our "uncertainty dependence" hypothesis, i.e. the conditional means $M_{j t}$, the conditional standard deviations $\sqrt{H_{j t}}$ and the output gap $G A P_{j t}$, are unchanged, with only the coefficient on the three-month interbank rate $R 3 M_{j t}$, less crucially, turning out insignificant.

We then further examine whether small and large banks show differences in discretionary loan charge-off behavior. ${ }^{19}$ To this end we augment Equation (4) with interaction terms between $M_{j t}, \sqrt{H_{j t}}, G A P_{j t}$ and $R 3 M_{j t}$ (i.e. all four variables of our "uncertainty dependence" hypothesis) and a bank size dummy variable $\left(\right.$ Dum $\left._{s m}\right)$ (see Table 3). We observe that large banks' behavior is consistent with our previous results, with the coefficients on the four variables of our "uncertainty dependence" hypothesis similarly significant and displaying identical signs. Performing Wald tests on the joint significance of the four interaction terms, we find that small banks' behavior in this regard appears significantly different. Further Wald tests indicate that, apart from the coefficient on $G A P_{j t}$ which is not significantly different from the one for large banks, the loan charge-off behavior of small banks is not well described by our "uncertainty dependence" hypothesis; this could be explained by the fact that small banks might generally have less margin for such discretionary behavior. We also interact the interaction term $G A P_{j t} \cdot I_{S m o o t h} h_{i t}$ with our bank size dummy; we find that only small banks' net charge-off behavior could be affected by their desire to obscure their income smoothing behavior.

\section{[Insert Table 3]}

\section{Conclusion}

The previous literature on banks' motivation to pursue discretionary loan chargeoffs has mostly focused on the issues of capital management and income smoothing. Both of these objectives are likely to be considered as undesirable by both

\footnotetext{
${ }^{19}$ We have 85 (139) banks with total assets larger (smaller) than 1 billion euros.
} 
welfare-maximizing bank regulators and transparency-seeking accounting standard setters. We stress the importance of a potential third rationale for a discretionary approach to the timing of a bank's loan charge-offs that is related to the real options nature of that decision in a context of uncertainty.

To examine this "uncertainty dependence" aspect, we develop a stylized real options model of a bank's decision whether to foreclose on and charge off a nonperforming secured loan when there is a chance of loan recovery and the expected present (net) value of potentially reclaimed collateral is uncertain. We find that increased uncertainty about the value of collateral increases the bank's tendency to delay the process of loan foreclosure and charge-off. A loan recovery becoming more probable, e.g. when general economic conditions improve, can either reduce or, more intuitively, increase the bank's incentives to hold back on the loan foreclosure and charge-off process; this depends on the extent to which economic conditions impact on the trend in the market value of collateral.

The main message of our model is that when a bank has the leeway to exercise discretion in the timing of its loan charge-offs, it can properly take into account the real options value implicit in the loan charge-off decision. Such discretionary loan charge-off behavior might thus be in line with a welfare maximizing regulator's objectives, although it might be difficult to distinguish from the one driven by capital management and income smoothing objectives; a more rules-focused accounting standards setter would most likely be opposed to the lack of transparency in this approach.

Our theoretical model implies the empirical hypothesis that banks' discretionary loan charge-offs might show a degree of "uncertainty dependence"; we empirically test this using a panel of European banks over the period 1994 to 2005 , controlling for the two other potential types of discretionary loan chargeoff behavior related to capital management and income smoothing objectives. Our results confirm the existence of a discretionary, uncertainty-related factor in European banks' loan charge-off behavior, which is consistent with the main features highlighted in our theoretical model. Our results also show that European banks 
might possibly be smoothing their income by using matching discretionary loan charge-offs in an attempt to obscure this behavior. The loan charge-off behavior of European banks does, however, not seem to be driven by a capital management objective; this is not very surprising given the limited ability to do so more generally from Basel I onwards.

Overall, banks' loan charge-off behavior appears to be a complex process influenced by various considerations, some of which are unobservable management objectives. Bank regulators might in this context face a difficult trade-off: on the one hand, they might want to leave banks enough discretion to allow them to properly account for the real options values implicit in their loan charge-off decision making under uncertainty. On the other, they might have an incentive to limit as much as possible the possibility that loan charge-offs are to a large extent timed in order to essentially "deceive" regulators; in this their incentives would largely coincide with those of accounting standards setters. This regulatory tradeoff is all the more relevant as it may have an impact on the banks' intertemporal loan supply more generally; this might indicate a promising direction for future research.

\section{A Appendix}

Proof. (Proposition 1) For the bank, not to foreclose on and charge off the nonperforming loan for a further instant $d t$ is optimal in the continuation region of the optimal stopping problem eq. (1), giving the relevant Bellman equation as $\mu F\left(L_{n}, L_{w}\right)=\frac{1}{d t} E\left[d F\left(L_{n}, L_{w}\right)\right]$. Applying Ito's Lemma, noting that the value function $F\left(L_{n}, L_{w}\right)$ should be homogeneous of degree $1,{ }^{20}$ so that $F\left(L_{n}, L_{w}\right)=$ $L_{w} f(\Gamma)$ where $\Gamma \equiv \frac{L_{n}}{L_{w}}$, we obtain $\frac{1}{2} \sigma^{2} \Gamma^{2} f^{\prime \prime}(\Gamma)-(\alpha-\eta \lambda) \Gamma f^{\prime}(\Gamma)+(\alpha-$ $\mu-(1+\eta) \lambda) f(\Gamma)+\lambda f(0)=0$ as the differential equation that characterizes the evolution of $f(\Gamma)$ in that region. We solve by standard methods, using the value-matching and smooth-pasting conditions $f\left(\Gamma^{*}\right)=\Gamma^{*}-1$ and

\footnotetext{
${ }^{20}$ This adopts the solution strategy in Dixit and Pindyck (1994, p. 210).
} 
$\frac{\partial f\left(\Gamma^{*}\right)}{\partial \Gamma}=1$; imposing the convergence condition $^{21} \mu+\lambda-\phi>0$, where $\phi=\alpha-\eta \lambda$, and applying the boundary condition $f(0)=0$, we obtain $\Gamma^{*}=$ $\frac{\sigma^{2}-2 \phi+4(\mu+\lambda)+\sqrt{8(\mu+\lambda) \sigma^{2}+\left(2 \phi-\sigma^{2}\right)^{2}}}{4(\mu+\lambda)}>1$ as the critical (trigger) value $\Gamma^{*}=\left(\frac{L_{n}}{L_{w}}\right)^{*}$ of relative expected discounted losses; ${ }^{22}$ it separates the region in $\left(L_{n}, L_{w}\right)$ space where the bank's option to foreclose on and charge off the non-performing loan remains unexercised (i.e. for $\frac{L_{n}}{L_{w}}<\left(\frac{L_{n}}{L_{w}}\right)^{*}$ ) from the one where immediate exercise of that option is perceived as optimal (i.e. for $\frac{L_{n}}{L_{w}} \geq\left(\frac{L_{n}}{L_{w}}\right)^{*}$ ).

Proof. (Proposition 2) We obtain $\frac{\partial\left(\frac{L_{n}}{L_{w}}\right)^{*}}{\partial \sigma}=\frac{\sigma}{2(\mu+\lambda)}\left(1+\frac{2(2(\mu+\lambda)-\phi)+\sigma^{2}}{\sqrt{\Psi}}\right)>0$, with $\Psi \equiv 8(\mu+\lambda) \sigma^{2}+\left(2 \phi-\sigma^{2}\right)^{2}>0$ and $2(\mu+\lambda)-\phi>0$ by assumption. Also, $\frac{\partial\left(\frac{L_{n}}{L_{w}}\right)^{*}}{\partial \phi}=\frac{\partial\left(\frac{L_{n}}{L_{w}}\right)^{*}}{\partial \alpha}=-\frac{1}{2(\mu+\lambda)}\left(1-\frac{2 \phi-\sigma^{2}}{\sqrt{\Psi}}\right)<0$, as $\frac{b}{\sqrt{a+b^{2}}}<1$ for $a>0$. Analogously, $\frac{\partial\left(\frac{L_{n}}{L_{w}}\right)^{*}}{\partial \eta}=\frac{\lambda}{2(\mu+\lambda)}\left(1-\frac{2 \phi-\sigma^{2}}{\sqrt{\Psi}}\right)>0$.

Further, $\frac{\partial\left(\frac{L_{n}}{L_{w}}\right)^{*}}{\partial \mu}=-\frac{\sqrt{\Psi}}{4(\mu+\lambda)^{2}}\left(1-\frac{4(\mu+\lambda) \sigma^{2}+\left(2 \phi-\sigma^{2}\right) \sqrt{\Psi}}{\Psi}\right)<0$. This holds as the (expanded) term in brackets is of form $1-\frac{a+b \sqrt{b^{2}+2 a}}{b^{2}+2 a}$, and thus positive if $\frac{a+b \sqrt{b^{2}+2 a}}{b^{2}+2 a}<1$. As $a>0$, this implies $b \sqrt{b^{2}+2 a}<b^{2}+a$; this holds trivially for $b \leq 0$, and implies $b^{2}\left(b^{2}+2 a\right)<\left(b^{2}+a\right)^{2}$ for $b>0$ which also holds.

Lastly, $\frac{\partial\left(\frac{L_{n}}{L_{w}}\right)^{*}}{\partial \lambda}=-\frac{4(\mu+\lambda)-\left(2 \phi-\sigma^{2}\right)+\sqrt{\Psi}-(\mu+\lambda)\left(2(2+\eta)+\frac{-4 \eta \phi+2(2+\eta) \sigma^{2}}{\sqrt{\Psi}}\right)}{4(\mu+\lambda)^{2}}$. In order to sign this expression, one can solve the equation $\frac{\partial\left(\frac{L_{n}}{L_{w}}\right)^{*}}{\partial \lambda}=0$ for $\eta$ to obtain the unique positive real root $\eta^{*}=\frac{\sigma^{2}-2 \alpha+\sqrt{8 \mu \sigma^{2}+\left(\sigma^{2}-2 \alpha\right)^{2}}}{4 \mu}>0$ (as $b+\sqrt{a+b^{2}}>0$ for $a>0)$. As one can also show that $\frac{\partial\left(\frac{L_{n}}{L_{w}}\right)^{*}}{\partial \lambda}=\frac{\partial\left(\frac{L_{n}}{L_{w}}\right)^{*}}{\partial \mu}<0$ holds for $\eta=0$, with $\lim _{\eta \rightarrow \infty} \frac{\partial\left(\frac{L_{n}}{L_{w}}\right)^{*}}{\partial \lambda}=\infty$, it follows that $\frac{\partial\left(\frac{L_{n}}{L_{w}}\right)^{*}}{\partial \lambda} \geq 0$ for $\eta \geq \eta^{*}$, and $\frac{\partial\left(\frac{L_{n}}{L_{w}}\right)^{*}}{\partial \lambda}<0$ for $0 \leq \eta<\eta^{*}$.

\footnotetext{
${ }^{21}$ This is sufficient to ensure real roots.

${ }^{22}$ Note that $\Gamma^{*}>1$ holds as $b+\sqrt{a+b^{2}}>0$ for $a>0$.
} 


\section{References}

Anandarajan, A., I. Hasan and C. McCarthy, 2007. Use of Loan Loss Provisions for Capital, Earnings Management and Signalling By Australian Banks. Accounting and Finance 47-3, 357-379.

Arellano, M. and S. R. Bond, 1991. Some Tests of Specification for Panel Data: Monte Carlo Evidence and an Application to Employment Equations. Review of Economic Studies 58-2, 277-297.

Arellano, M. and O. Bover, 1995. Another Look at the Instrumental Variables Estimation of Errorcomponents Models. Journal of Econometrics 68-1, 29-51.

Baba, N., 2001. Optimal timing in banks' write-off decisions under the possible implementation of a subsidy scheme: a real options approach. Bank of Japan Monetary and Economic Studies 19-3, 113-141.

Basel Committee on Banking Supervision, 2009. Guiding principles for the replacement of IAS 39. Basel: Bank of International Settelments.

Beatty, A., S. Chamberlain and J. Magliolo, 1995. Managing financial reports of commercial banks: The influence of taxes, regulatory capital, and earnings. Journal of Accounting Research 33-2, 231-261.

Benston, J.B. and L.D. Wall, 2005. How should banks account for loan losses. Journal of Accounting and Public Policy 24-2, 81-100.

Bollerslev, T., 1986. Generalised Autoregressive Conditional Heteroskedasticity. Journal of Econometrics 31-3, 307-327.

Bollerslev, T. and J.M. Wooldridge, 1992. Quasi-Maximum Likelihood Estimation and Inference in Dynamic Models with Time Varying Covariances. Econometric Reviews 11-2, 143-172. 
Cargill, T.F., M.M. Hutchison and T. Ito, 1997. The Political Economy of Japanese Monetary Policy. Cambridge \& London: MIT Press.

Chen, N.K. and H.L. Chu, 2003. Collateral Value and Forbearance Lending. Discussion Paper CEPDP0603. Centre for Economic Performance, London School of Economics.

Collins, J., D. Shackelford and J. Wahlen, 1995. Bank differences in the coordination of regulatory capital, earnings, and taxes. Journal of Accounting Research 33-2, 263-291.

Dixit, A. and R. Pindyck, 1994. Investment under Uncertainty. Princeton NJ: Princeton University Press.

Engle, R.F., 1982. Autoregressive Conditional Heteroskedasticity with Estimates of the Variance of U.K. Inflation, Econometrica 50-4, 987-1008.

Fudenberg, D. and J. Tirole, 1995. A Theory of Income and Dividend Smoothing Based on Incumbency Rents. Journal of Political Economy 103-1, 75-93.

Kim, M.S. and W. Kross, 1998. The impact of the 1989 change in bank capital standards on loan loss provisions and loan write-offs. Journal of Accounting and Economics 25-1, 69-99.

Laurin, A. and G. Majnoni, 2003. Bank Loan Classification and Provisioning Practices in Selected Developed and Emerging Countries. Washington DC: World Bank.

Liu, C.C. and S.G. Ryan, 2006. Income Smoothing Over the Business Cycle: Changes in Banks Coordinated Management of Provisions for Loan Losses and Loan Charge-Offs from the Pre-1990 Bust to the 1990s Boom. The Accounting Review 81-2, 421-441.

McDonald, R. and D. Siegel, 1986. The value of waiting to invest. Quarterly Journal of Economics 101-4, 707-727. 
Moyer, S., 1990. Capital adequacy regulations and accounting changes in commercial banks. Journal of Accounting and Economics 13-2, 123-154.

Peek, J. and E.S. Rosengren, 2005. Unnatural Selection: Perverse Incentives and the Misallocation of Credit in Japan. American Economic Review 95-4, 11441166.

Schüle, T., 2007. Forbearance Lending and Soft Budget Constraints in Multiple Bank Financing. Journal of Institutional and Theoretical Economics 163-3, 448466.

Sekine, T., K. Kobayashi and Y. Saita, 2003. Forbearance Lending: The Case of Japanese Firms. Bank of Japan Monetary and Economic Studies 21-2, 69-92.

Watts, R.L. and J.L. Zimmerman, 1990. Positive Accounting Theory: A Ten Year Perspective. The Accounting Review 65-1, 131-153.

Watts, R.L. and J.L. Zimmerman, 1986. Positive Accounting Theory. Englewood Cliffs NJ: Prentice-Hall. 
Table 1. Descriptive statistics for European commercial, savings and cooperative \& mutual banks, on average over the period $1994-2005$

\begin{tabular}{|c|c|c|c|c|c|c|c|c|c|c|c|c|c|}
\hline & DEPOSIT & LOAN & $\mathrm{PE}$ & ROA & ROE & NIM & NNIR & EQUITY & TCR & LLP & $\mathrm{NCO}$ & NPL & TA \\
\hline \multicolumn{14}{|c|}{ Full sample of banks available under Bankscope (4853 banks) } \\
\hline Mean & 54.85 & 53.60 & 1.56 & 0.64 & 7.27 & 3.06 & 29.14 & 9.87 & 17.70 & 1.00 & 0.57 & 6.67 & 5354229 \\
\hline Minimum & 0 & 0 & 0 & -37.34 & -95.39 & -4.88 & -98.37 & 0.10 & 0.10 & -50.00 & -0.88 & 0 & 36 \\
\hline Maximum & 99.81 & 99.00 & 23.75 & 39.83 & 97.01 & 76.69 & 187.27 & 98.80 & 79.00 & 97.26 & 9.91 & 39.98 & $1.33 \mathrm{E}+09$ \\
\hline Std. Dev. & 24.21 & 24.11 & 1.41 & 1.91 & 10.27 & 2.26 & 24.00 & 11.20 & 9.36 & 3.38 & 1.03 & 6.45 & 36915223 \\
\hline \multicolumn{14}{|c|}{ Our sample (constrained by availability of net charge-offs, total capital ratio and loan loss reserves) } \\
\hline \multicolumn{14}{|c|}{ All banks (224 banks) } \\
\hline Mean & 55.87 & 61.75 & 1.34 & 0.81 & 10.36 & 3.06 & 25.56 & 8.83 & 14.95 & 0.50 & 0.45 & 5.33 & 40620937 \\
\hline Minimum & 0.39 & 6.94 & 0.12 & -15.97 & -53.39 & 0.43 & -36.51 & 2.08 & 3.10 & -1.22 & -0.63 & 0.00 & 39099 \\
\hline Maximum & 87.38 & 98.13 & 2.45 & 4.53 & 37.82 & 7.91 & 80.35 & 33.23 & 61.27 & 27.21 & 3.55 & 33.10 & $9.92 \mathrm{E}+08$ \\
\hline Std. Dev. & 15.82 & 18.00 & 0.37 & 0.90 & 7.15 & 0.96 & 14.30 & 3.87 & 6.74 & 1.30 & 0.54 & 4.96 & $1.27 \mathrm{E}+08$ \\
\hline Mean 1994-1999 & 58.56 & 52.62 & 1.63 & 1.01 & 11.00 & 4.29 & 25.17 & 9.36 & 16.73 & 0.72 & 0.70 & 5.29 & 16907945 \\
\hline Mean 2000-2005 & 52.50 & 61.99 & 1.41 & 0.79 & 7.38 & 3.20 & 21.35 & 11.07 & 17.98 & 0.47 & 0.33 & 7.65 & 17721361 \\
\hline
\end{tabular}

Variable definitions (all ratios are expressed in percentages): DEPOSIT = deposits/total assets; LOAN = gross loans/total assets; PE=personnel expenses/total assets; $R O A=$ return on average assets; ROE = return on average equity; NIM = net interest margin; NNIR = net non-interest revenue/total operating income; EQUITY = equity/total assets; TCR = total capital ratio; LLP= loan loss provisions/gross loans; NCO = net charge-offs/gross loans; NPL = non performing loans/gross loans; TA = total assets in thousands of euros. 
Table 2. Determinants of banks' charge-off behavior (Arellano and Bond (1991) and Arellano and Bover (1995) estimators)

\begin{tabular}{|c|c|c|}
\hline & $\begin{array}{l}\text { Arrellano and Bond } \\
\text { (First differences) }\end{array}$ & $\begin{array}{l}\text { Arrellano and Bover } \\
\text { (Orthogonal deviations) }\end{array}$ \\
\hline$\underset{(+)}{\mathrm{NCO}_{\mathrm{it}-1}}$ & $\begin{array}{l}0.089 * * * \\
(16.737)\end{array}$ & $\begin{array}{l}0.124 * * * \\
(13.697)\end{array}$ \\
\hline$\underset{(+)}{\mathrm{NPL}_{\mathrm{it}-1}}$ & $\begin{array}{c}0.019 * * \\
(2.430)\end{array}$ & $\begin{array}{l}0.024 * * * \\
(5.266)\end{array}$ \\
\hline$\underset{(+)}{\mathrm{TCR}_{\mathrm{it}-1}}$ & $\begin{array}{c}-0.003 \\
(-0.525)\end{array}$ & $\begin{array}{c}0.002 \\
(0.305)\end{array}$ \\
\hline $\begin{array}{c}\mathrm{M}_{\mathrm{jt}} \\
(-)\end{array}$ & $\begin{array}{c}-0.013 * * * \\
(-10.353)\end{array}$ & $\begin{array}{c}-0.011 * * * \\
(-25.373)\end{array}$ \\
\hline$\underset{(-)}{\sqrt{\mathrm{H}_{\mathrm{jt}}}}$ & $\begin{array}{c}-0.004 * * * \\
(-11.417)\end{array}$ & $\begin{array}{c}-0.005^{* * *} \\
(-5.383)\end{array}$ \\
\hline$\underset{(+)}{\mathrm{GAP}_{\mathrm{jt}}}$ & $\begin{array}{c}-0.029 * * * \\
(-3.655)\end{array}$ & $\begin{array}{c}-0.050 * * * \\
(-8.008)\end{array}$ \\
\hline$\underset{(+)}{\mathrm{R} 3 \mathrm{M}_{\mathrm{jt}}}$ & $\begin{array}{c}0.033 * * * * \\
(8.005)\end{array}$ & $\begin{array}{c}0.024 * * * \\
(9.307)\end{array}$ \\
\hline $\mathrm{GAP}_{\mathrm{jt}} \cdot \mathrm{ISmooth}_{(+)}$ & $\begin{array}{c}0.001 \\
(1.523)\end{array}$ & $\begin{array}{c}0.003 * * \\
(2.488)\end{array}$ \\
\hline $\begin{array}{c}\text { J-Statistic } \\
(\mathrm{P} \text {-value, Sargan test) }\end{array}$ & $\begin{array}{l}55.662 \\
(0.412) \\
\end{array}$ & $\begin{array}{l}55.497 \\
(0.380)\end{array}$ \\
\hline Observations & 481 & 481 \\
\hline
\end{tabular}

$* * *, * *$ and $*$ indicate significance at $1 \%, 5 \%$ and $10 \%$ levels, respectively; T-statistics are given in brackets. Variable definitions: $\mathrm{NCO}_{\mathrm{it}}=$ ratio net charge-offs/gross loans; $\mathrm{NPL}_{\mathrm{it}}=$ ratio nonperforming loans/gross loans; $\mathrm{TCR}_{\mathrm{it}}=$ total capital ratio; $\mathrm{M}_{\mathrm{jt}}$ and $\sqrt{\mathrm{H}_{\mathrm{jt}}}=$ conditional mean and conditional standard deviation from a $\operatorname{GARCH}(1,1)$ single factor market model of real estate stock index returns; $\mathrm{GAP}_{\mathrm{jt}}=$ output gap, using a Hodrick-Prescott filter; $\mathrm{R}_{3} \mathrm{M}_{\mathrm{jt}}=$ three-month interbank rate;

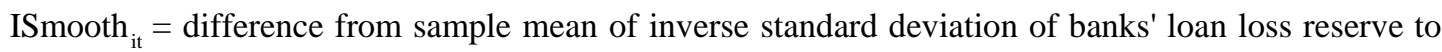
gross loans ratio, calculated using three-period moving windows. 
Table 3. Uncertainty dependence hypothesis by banks' size (Arellano and Bond (1991) and Arellano and Bover (1995) estimators)

\begin{tabular}{|c|c|c|}
\hline & $\begin{array}{c}\text { Arrellano and Bond } \\
\text { (First differences) }\end{array}$ & $\begin{array}{c}\text { Arrellano and Bover } \\
\text { (Orthogonal deviations) }\end{array}$ \\
\hline $\mathrm{NCO}_{\text {it-1 }}$ & $\begin{array}{c}0.083 * * * \\
(7.152)\end{array}$ & $\begin{array}{c}0.123 * * * \\
(11.062)\end{array}$ \\
\hline $\mathrm{NPL}_{\mathrm{it}-1}$ & $\begin{array}{c}0.027 * * * \\
(3.825)\end{array}$ & $\begin{array}{c}0.020^{* *} \\
(2.532)\end{array}$ \\
\hline $\mathrm{TCR}_{\mathrm{it}-1}$ & $\begin{array}{l}-0.003 \\
(-0.419)\end{array}$ & $\begin{array}{c}0.003 \\
(0.518)\end{array}$ \\
\hline $\mathrm{M}_{\mathrm{jt}}$ & $\begin{array}{r}-0.015 * * * \\
(-16.047)\end{array}$ & $\begin{array}{l}-0.012 * * * \\
(-17.577)\end{array}$ \\
\hline$\sqrt{\mathrm{H}_{\mathrm{jt}}}$ & $\begin{array}{r}-0.005 * * * \\
(-11.728)\end{array}$ & $\begin{array}{c}-0.004 * * * \\
(-3.562)\end{array}$ \\
\hline $\mathrm{GAP}_{\mathrm{jt}}$ & $\begin{array}{c}-0.038 * * * \\
(-2.679)\end{array}$ & $\begin{array}{c}-0.055^{* * * *} \\
(-5.398)\end{array}$ \\
\hline $\mathrm{R} 3 \mathrm{M}_{\mathrm{jt}}$ & $\begin{array}{c}0.045^{* * * *} \\
(9.352)\end{array}$ & $\begin{array}{c}0.030 * * * \\
(9.385)\end{array}$ \\
\hline $\mathrm{GAP}_{\mathrm{jt}} \cdot \mathrm{ISmooth}_{\mathrm{it}}$ & $\begin{array}{c}-0.008 * * * \\
(-3.846)\end{array}$ & $\begin{array}{c}-0.007 * * * \\
(-2.965)\end{array}$ \\
\hline $\operatorname{Dum}_{\mathrm{sm}} \cdot \mathrm{M}_{\mathrm{jt}}$ & $\begin{array}{c}0.013 * * * \\
(3.696)\end{array}$ & $\begin{array}{c}0.011 * * * \\
(3.709)\end{array}$ \\
\hline $\operatorname{Dum}_{\mathrm{sm}} \cdot \sqrt{\mathrm{H}_{\mathrm{jt}}}$ & $\begin{array}{c}0.008 * * * \\
(3.501)\end{array}$ & $\begin{array}{r}0.007 * * \\
(1.963)\end{array}$ \\
\hline $\operatorname{Dum}_{\mathrm{sm}} \cdot \mathrm{GAP}_{\mathrm{jt}}$ & $\begin{array}{c}-0.002 \\
(-0.036)\end{array}$ & $\begin{array}{c}0.030 \\
(0.838)\end{array}$ \\
\hline $\operatorname{Dum}_{\mathrm{sm}} \cdot \mathrm{R} 3 \mathrm{M}_{\mathrm{jt}}$ & $\begin{array}{c}-0.101 * * * \\
(-4.802)\end{array}$ & $\begin{array}{c}-0.074 * * * \\
(-4.124)\end{array}$ \\
\hline $\mathrm{DUM}_{\mathrm{sm}} \cdot \mathrm{GAP}_{\mathrm{jt}} \cdot \mathrm{ISmooth}_{\mathrm{it}}$ & $\begin{array}{c}0.015 * * * \\
(3.340)\end{array}$ & $\begin{array}{c}0.011 * * * \\
(2.911)\end{array}$ \\
\hline $\begin{array}{c}\text { J-Statistic } \\
\text { (P-value, Sargan test) }\end{array}$ & $\begin{array}{l}45.775 \\
(0.715) \\
\end{array}$ & $\begin{array}{l}25.106 \\
(0.999) \\
\end{array}$ \\
\hline Observations & 481 & 481 \\
\hline
\end{tabular}

$* * *, * *$ and $*$ indicate significance at $1 \%, 5 \%$ and $10 \%$ levels, respectively; T-statistics are given in brackets. Variable definitions: $\mathrm{NCO}_{\mathrm{it}}=$ ratio net charge-offs/gross loans $; \mathrm{NPL}_{\mathrm{it}}=$ ratio nonperforming loans/gross loans; $\mathrm{TCR}_{\mathrm{it}}=$ total capital ratio; $\mathrm{M}_{\mathrm{jt}}$ and $\sqrt{\mathrm{H}_{\mathrm{jt}}}=$ conditional mean and conditional standard deviation from a $\operatorname{GARCH}(1,1)$ single factor market model of real estate stock index returns; $\mathrm{GAP}_{\mathrm{jt}}=$ output gap, using a Hodrick-Prescott filter; $\mathrm{R} 3 \mathrm{M}_{\mathrm{jt}}=$ three-month interbank rate; ISmooth $_{\mathrm{it}}=$ difference from sample mean of inverse standard deviation of banks' loan loss reserve to gross loans ratio, calculated using three-period moving windows; Dum $\mathrm{sm}_{\mathrm{m}}=$ dummy variable which is 1 if the average of total assets of the bank over the period 1994-2005 is smaller than 1 billion euros, and 0 otherwise. 